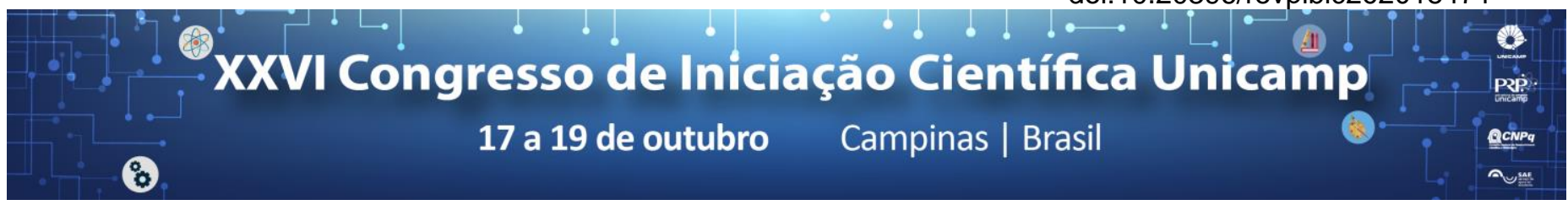

\title{
Simulação numérica de campos de temperaturas em edificações.
}

\author{
Gabriel Armbrust Castanho de Mello Arruda*, Saulo J. C. Almeida
}

\section{Resumo}

No presente trabalho buscou-se analisar o comportamento em situação de incêndio de uma edificação comumente destinada ao público estudantil por meio de softwares de modelagem computacional. Uma edificação foi modelada seguindo o mesmo padrão arquitetônico, bem como os diferentes materiais construtivos comumente utilizados na prática da engenharia. Por meio dos campos de temperaturas obtidos avaliou-se se arquitetura e materiais construtivos dessas edificações são parâmetros importantes para segurança contra incêndio das mesmas.

\section{Palavras-chave:}

Simulação numérica, Fluidodinâmica computacional, Campo Térmico.

\section{Introdução}

A área da construção civil encontra-se em desenvolvimento constante, com novas técnicas construtivas e materiais. Porém, as normas, cujo objetivo é promover a segurança das edificações em situação de incêndio, não têm se desenvolvido no mesmo ritmo que os aspectos supracitados.

O número crescente de novos parâmetros exige estudos que gerem o conhecimento necessário para promover segurança contra incêndio e que avaliem se as novas possibilidades construtivas atendem aos critérios normativos. Tendo em vista que os desempenhos construtivo e estrutural estão diretamente ligados à curva de elevação de temperatura, é importante conhecer como as novas técnicas construtivas e materiais afetam a mesma.

Por meio da simulação computacional de incêndio é possível identificar e avaliar a influência do material construtivo utilizado no aumento da temperatura do ambiente. Para esse processo foi utilizado o Fire Dynamics Simulator - FDS, que permite modelagens mais realísticas dos parâmetros envolvidos na deflagração e propagação de incêndio em edificações.

\section{Resultados e Discussão}

O estudo de caso realizado envolveu a edificação de uma Kitnet próxima ao campus Zeferino Vaz da Universidade Estadual de Campinas - UNICAMP, dividida em três ambientes, quarto, cozinha e banheiro, com $31 \mathrm{~m}^{2}$, conforme figura $1 \mathrm{a}$.

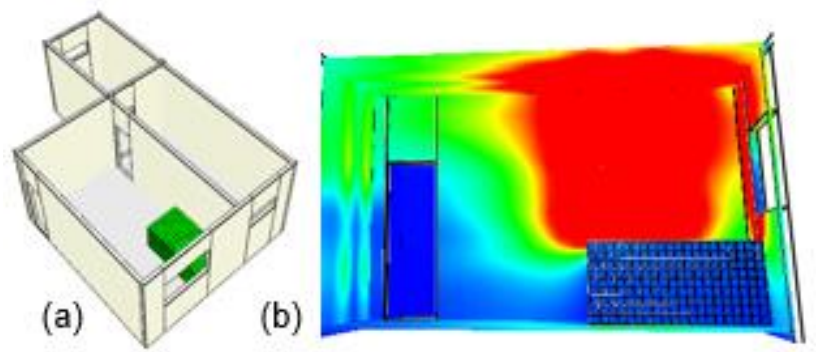

Figura 1. (a) Modelo Computacional da estrutura e (b) resultado gráfico da simulação.

Para tal edificação, foram utilizados o concreto, placas de gesso e placas de madeira MDP. Foi adotado um objeto como foco de incêndio e obtidas as curvas de temperatura vs. tempo nas superfícies das paredes e no ambiente com o uso de cada material.

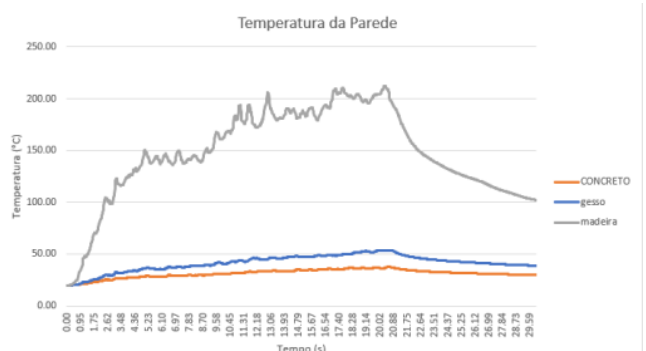

Figura 2. Curvas obtidas na simulação de Incêndio.

Conforme figura 2, as curvas temperatura vs. tempo obtidas deixam em evidência a influência do material construtivo na evolução do incêndio. Naturalmente, a madeira alcança temperaturas mais elevadas por também servir como combustível.

\section{Conclusões}

$\mathrm{Na}$ avaliação de segurança das edificações em situação de incêndio é importante avaliar o desempenho de acordo com o material construtivo utilizado, considerando as diferentes reações a altas temperaturas.

Além disso, é importante a realização de simulações com todos objetos existentes no ambiente e que também sirvam de combustível, a fim de analisar cenários de incêndios mais realísticos para a edificação.

As investigações sobre segurança contra incêndio em edificações devem avançar de forma mais incisiva na avaliação com base no desempenho.

\section{Agradecimentos}

Agradeço a Deus pela vida e oportunidade, à família pelo suporte, ao Professor Doutor Saulo Almeida pela orientação acadêmica e ao Conselho Nacional de Desenvolvimento Científico e Tecnológico (CNPq) pelo apoio à pesquisa.

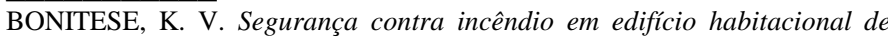
baixo custo estruturado em aço. 2007. 278 f. Dissertação (Mestrado em Construção Civil) - Curso de Pós-graduação em Construção Civil, Universidade Federal de Minas Gerais, Belo Horizonte.

NUNES, H. M. C. Modelação da Propagação de Incêndios em Edifícios Análise do Comportamento Estrutural em Situação de Incêndio. 2015. $202 \mathrm{f}$ Dissertação (Mestrado em Engenharia Civil) - Curso de Engenharia Civil, Instituto Superior de Engenharia de Coimbra, Coimbra. 